Archives of Agriculture and Environmental Science

\title{
Performance of locally discovered rice cultivar (Haridhan) in Bangladesh under urea sprays technology
}

\author{
Ekramul Haque, Md. Rashedur Rahman* (D) and Abdul Kader
}

Department of Agronomy, Faculty of Agriculture, Bangladesh Agricultural University, Mymensingh - 2202, BANGLADESH "Corresponding author's E-mail: rashedagron@bau.edu.bd

\section{ARTICLE HISTORY}

Received: 25 May 2019

Revised received: 03 June 2019

Accepted: 05 June 2019

\section{Keywords}

Crop characteristics

HYV of rice

Locally discovered rice

Urea spray

Yield contributing characters

\section{ABSTRACT}

The research work was conducted at the Agronomy Field Laboratory, Department of Agronomy, Bangladesh Agricultural University, Mymensingh during the period from July to November 2015 to evaluate the yield performance of BRRI dhan56 and a locally discovered rice cultivar Haridhan under foliar and traditional application of urea. The experiment included six treatments of urea application technique as $\mathrm{T}_{1}=\mathrm{N}_{0}$ (control), $\mathrm{T}_{2}=\mathrm{N}_{65 \%}, \mathrm{~T}_{3}=\mathrm{N}_{50 \%}+\mathrm{US}$ (15\%), $\mathrm{T}_{4}=\mathrm{N}_{50 \%}+\mathrm{US}(20 \%), \mathrm{T}_{5}=\mathrm{N}_{60 \%}+\mathrm{US}(15 \%), \mathrm{T}_{6}=\mathrm{N}_{100 \%}$ (traditional method) and two rice varieties viz. HYV rice cultivar BRRI dhan56 and locally discovered rice cultivar Haridhan. The experiment was laid out in a randomized complete block design (RCBD) with three replications. Foliar application of urea had significant effect on yield and yield components of BRRI dhan56 and Haridhan. It has been found that the treatment $\mathrm{N}_{50 \%}+\mathrm{US}$ (20\%) produced highest grain yield $\left(6.14 \mathrm{t} \mathrm{ha}^{-1}\right)$ which might be due to the highest number of total tillers hill ${ }^{-1}(15.03)$, effective tillers hill ${ }^{-1}(12.11)$, panicle length $(26.21 \mathrm{~cm})$ and grains panicle ${ }^{-1}(156.91)$ got from this treatment. From the result it can be concluded that both the varieties produced highest grain yield with $50 \%$ of the required urea applied to the soil and $20 \%$ of the required urea applied as foliar spray that can save an amount of $30 \%$ of recommended dose of urea in rice field of Bangladesh

(C)2019 Agriculture and Environmental Science Academy

Citation of this article: Haque, E., Rahman, M.R. and Kader, A. (2019). Performance of locally discovered rice cultivar (Haridhan) in Bangladesh under urea sprays technology. Archives of Agriculture and Environmental Science, 4(2): 235-241, https:// dx.doi.org/10.26832/24566632.2019.0402017

\section{INTRODUCTION}

Bangladesh is an agro based country where agriculture is the single largest sector and the main of country economy (Sabnam, 2013). Rice (Oryza sativa L.) is the most extensively cultivated cereal crop in Bangladesh. Rice (Oryza sativa L.) is also the staple food for more than two millions of people in Africa and Latin America (Akter, 2017). In 2015-16, 475.64 million metric tons rice where consumed worldwide (Statistica, 2018). It provides nearly $48 \%$ of rural employment, about two-third of total calorie supply and about one-half of the total protein intakes of an average person in the country (BBS, 2011). Bangladesh is a densely populated country and at present its population growth rate is $1.37 \%$ (BBS, 2017). Rice crop area is decreasing day by day due to high population pressure. Therefore, attempts should be taken to increase the yield per unit area by applying improved technology and proper management of fertilizers to achieve the goal of self-sufficiency in rice production. Use of high yielding variety has been increased remarkably in recent years and the country has almost reached a level of sufficiency in rice. Some reasons of higher production may be due to high response to fertilizers especially nitrogenous fertilizers. The importance of the role of nitrogenous fertilizer increasing rice yield has been widely recognized (Singh and Chauhan, 2001). However traditional method of urea application on the soil leads to various losses in soil mainly due to leaching, run off, volatilization and de nitrification. In such situation combination of urea spray on foliage and traditional application of urea (soil application) increase nitrogen use efficiency compared to conventionally applied prilled urea. Farmers of the country usually do not apply nitrogen in their fields properly and timely. It is estimated that only about $25 \%$ of the added nitrogen is 
utilize by the crops and the rest $75 \%$ is lost due to leaching, surface runoff, $\mathrm{NH}_{3}$ volatilization, decreased nitrification and other processes. Besides, at present the nitrogen fertilizer is very costly. So, it has become very expensive to apply sufficient amount of nitrogen fertilizers. Under these circumstances, it is important to find out the effective method of application of urea fertilizer that would give higher yield of crops and also reduce fertilizer cost. Chemical fertilizer, if applied in excess amount, has a harmful effect on soil physical, chemical and biological properties. It inhibits growth and development of soil microorganism. Therefore, excessive use of $\mathrm{N}$ fertilizer is one of the major concerns in sustainable agriculture for its decreased $\mathrm{N}$ utilization efficiency by crops and increased $\mathrm{N}$ released to the environment, resulting atmosphere and water systems pollution (Zhu et al., 1997). In Bangladesh, $\mathrm{N}$ fertilizer input is as high as $265 \mathrm{~kg} \mathrm{Nha}^{-11} \mathrm{yr}^{-1}$ in rice-rice cropping pattern (BBS, 2011). As foliar application reduces the use of excess chemical fertilizer, it will be beneficial for soil environment. In many cases aerial spray of nutrients is preferred and it gives quicker and better results than the soil application (Jamal et al., 2006). Foliar application of urea has a significant effect on yield (Moeini et al., 2006). Recently foliar application of nutrients has become an important practice in the production of crops while application of fertilizers to the soil remains the basic method of feeding the majority of the crop plants. Moreover, in Bangladesh context it has been reported that application of urea through foliar spray can reduce the requirement of urea fertilizer by $80 \%$ of soil application (AIS, 2008). So fertilizer cost can be greatly reduced. Considering the above facts an attempt has been taken to evaluate comparative yield performance of BRRI dhan 56 and locally discovered rice variety Haridhan under various methods of urea application and find out the optimum amount of urea fertilizer to be applied as foliar spray technique to obtain the highest grain yield.

\section{MATERIALS AND METHODS}

\section{Description of experimental site}

The experiment was conducted at Agronomy Field Laboratory of Bangladesh Agricultural University, Mymensingh during the period from July 2015 to Nov 2015. Geographically the experimental site is located at $24.75^{\circ} \mathrm{N}$ latitude and $90.50^{\circ} \mathrm{E}$ longitude at an elevation of $18 \mathrm{~m}$ above the mean sea level under the Agro -ecological Zone of the Old Brahmaputra Floodplain (FAO and UNDP, 1988).

\section{Characteristics of test variety}

\section{Haridhan}

Haridhan was used as the test variety in the study. It is one of the important rice cultivars developed by a farmer Haripad Kapali. It attains the height of $121.69 \mathrm{~cm}$ and grain yield reported by farmers is $6.08 \mathrm{t} \mathrm{ha}^{-1}$.The Department of Agricultural Extension of the Government after examining the paddy has declared Haridhan as a profitable cultivar. It costs little to cultivate. Moreover, compared to the profuse growth, the expenditure for its cultivation seems to be very little. The farmers are getting bumper yield from Haridhan.

\section{BRRI dhan56}

Variety BRRI dhan 56 was first evaluated by the Seed Certification Agency (SCA) in 2010. Then it was released by the National Seed Board (NSB) in 2011 as a drought tolerant variety. The cultivation of newly developed rice variety 'BRRI dhan56' in the current Aman season brought smile on the faces of the farmers in the country's northern and south-western regions where aridity used to lead to crop failure to their woes. This variety have ushered a new era in rice cultivation during 'Monga' period in the drought prone areas to mitigate 'Monga'. Researchers said BRRI dhan 56 is a short-duration variety which is cultivated during Aman season. It is also disease resistant variety, grain type is medium bold and plant attains a height of about $115 \mathrm{~cm}$. The yield of this variety is about (4.5- 5.0 tha $^{-1}$ ) in normal condition and in drought condition at about is 3.0-3.5 tha $^{-1}$.

\section{Preparation of the experimental land and raising of crop}

The experimental land was first opened with a power tiller. The land was thoroughly preapred with the help of country plough and ladder. Weeds and stubble were removed from the field. The bunds around individual plots were made for proper water management between the plots. The individual plots of each block were prepared thoroughly by spading and then levelled just before the specified date of transplanting. Thirty day old seedlings were uprooted carefully from the nursery bed and transplanted in the individual plot on 18 July 2015 at the rate of 2-3 seedlings hill ${ }^{-1}$ with a spacing of $25 \mathrm{~cm} \times 15 \mathrm{~cm}$. Various intercultural operations viz., irrigation, weeding, disease and pest management etc. were done and when necessary to ensure and maintain the favourable condition for normal plant growth and development.

\section{Layout of the experiment}

The experiment was laid out in a randomized complete block design (RCBD) with three replications. Individual plot size was $4 \mathrm{~m}$ $\times 2.5 \mathrm{~m}$. There were 36 plots in the experiment. The experiment was superimposed in the Agronomy Field Laboratory, where another student grew the same crop surrounding the experiment. The field was fertilized with triple super phosphate, muriate of potash and gypsum @ 52, 82, 60 kg ha-1, respectively. The whole amount of triple super phosphate, muriate of potash and gypsum was applied at final land preparation.

\section{Sampling, harvesting and processing}

The crop was harvested at full maturity. The date of harvesting was confirmed when $90 \%$ of the grains became golden yellow in color. Harvesting of BRRI dhan56 was done on 7 November 2015 and Haridhan was 27 Nov 2015. Five hills (excluding border hills) were selected randomly from each individual plot and uprooted before harvesting for recording data. After sampling the whole plot was harvested. The harvested crop of each plot was separately bundled, properly tagged and then brought to the threshing floor. The harvested crops were 
threshed manually. The grains were cleaned and dried to a moisture content of $14 \%$. Straws were sun dried properly. Final grain and straw yields plot $^{-1}$ were recorded and converted to t ha ${ }^{-1}$.

\section{RESULTS AND DISCUSSION}

\section{Crop characteristics}

\section{Plant height}

The difference of plant height between BRRI dhan56 $(110.47 \mathrm{~cm})$ and Haridhan $(121.69 \mathrm{~cm})$ might be due to genetic make-up variation (Table 1). Islam et al. (2012) and Tayeb et al. (2013) observed such variation in plant height due to varietal differences. The highest plant height $(118.50 \mathrm{~cm})$ was obtained from $\mathrm{T}_{3}$ treatment when $15 \%$ urea was applied as foliar spray which was higher than $T_{6}$ treatment (traditional method) (Table 2). The highest plant height $114.73 \mathrm{~cm}$ was obtained from $\mathrm{V}_{1} \mathrm{~T}_{3}$ treatment which is higher than traditional application of urea and highest plant height $123.13 \mathrm{~cm}$ from traditional application of urea which has not significant difference of the plant height $122.80 \mathrm{~cm}$ found from $\mathrm{V}_{2} \mathrm{~T}_{5}$ treatment when $15 \%$ urea used for foliar spray and $60 \%$ urea for traditional method. So interaction effect of variety and foliar application of urea was significant effect on plant height (Table 3).

\section{Total tillers hill $^{-1}$}

BRRI dhan56 and Haridhan produced total tillers hill ${ }^{-1}$ (11.92) and (15.58) (Table 1). Variable effect of variety on number of total tillers hill $^{-1}$ was also reported by Nuruzzaman et al. (2000), Jaiswal and Singh (2001) and Hossain et al. (2007) who noticed that number of totals tillers hill $^{-1}$ differed among the varieties. Number of total tillers hill ${ }^{-1}$ was significantly different among the varieties at transplanting dates up to harvesting. BRRI dhan56 and Haridhan produced highest number of total tillers hill $^{-1}$ in $\mathrm{T}_{4}$ treatment (when 20\% urea was applied as foliar spray) which was higher than $100 \%$ traditional application of urea. Number of total tillers hill $^{-1}$ was significantly influenced by foliar application of urea (Table 2). The number of total tillers hill ${ }^{-1}$ varied due to varietal differences of urea at different concentrations exhibited significant difference in producing number of total tillers hill ${ }^{-1}$ (Kabir et al., 2004). Interaction effect of variety and foliar application of urea was significant effect on total tillers hill ${ }^{-1}$ (Table 3).

Table1. Effect of variety on yield and yield contributing characters of BRRI dhan56 and Haridhan.

\begin{tabular}{llll}
\hline Variety & Plant height $(\mathrm{cm})$ & Total tiller hill $^{-1}$ & Panicle length $(\mathrm{cm})$ \\
\hline BRRI dhan56 & $110.47 \mathrm{~b}$ & $11.92 \mathrm{~b}$ & $24.89 \mathrm{~b}$ \\
Haridhan & $121.69 \mathrm{a}$ & $15.58 \mathrm{a}$ & $26.54 \mathrm{a}$ \\
CV (\%) & 3.25 & 5.01 & 5.62 \\
Level of sig. & $* *$ & $* *$ & $* *$ \\
\hline
\end{tabular}

In a column, figures with same letter or without letter do not differ significantly whereas figures with dissimilar letters differ significantly as per DMRT; ${ }^{*}=$ Significant at $5 \%{ }^{* *}=$ Significant at $1 \% \quad$ NS $=$ Non-significant.

Table 2. Effect of foliar spray of urea on the yield and yield contributing characters of BRRI dhan56 and Haridhan.

\begin{tabular}{llll}
\hline Treatment & Plant height $(\mathbf{c m})$ & Total tiller hill $^{-1}$ & Panicle length $(\mathbf{c m})$ \\
\hline $\mathrm{T}_{1}$ & $112.17 \mathrm{c}$ & $13.07 \mathrm{~b}$ & 25.29 \\
$\mathrm{~T}_{2}$ & $117.37 \mathrm{ab}$ & $13.97 \mathrm{~b}$ & 25.55 \\
$\mathrm{~T}_{3}$ & $118.50 \mathrm{a}$ & $13.57 \mathrm{~b}$ & 26.04 \\
$\mathrm{~T}_{4}$ & $115.07 \mathrm{bc}$ & $15.03 \mathrm{a}$ & 26.21 \\
$\mathrm{~T}_{5}$ & $117.15 \mathrm{ab}$ & $13.40 \mathrm{~b}$ & 25.70 \\
$\mathrm{~T}_{6}$ & $116.23 \mathrm{ab}$ & $13.47 \mathrm{~b}$ & 25.52 \\
$\mathrm{CV}(\%)$ & 3.25 & 5.01 & 5.62 \\
Level of sig. & $* *$ & $* *$ & $\mathrm{NS}$ \\
\hline
\end{tabular}

${ }^{*}=$ Significant at $5 \%,{ }^{* *}=$ Significant at $1 \%$, NS=Non significant; In a column, figures with same letter or without letter do not differ significantly whereas figures with dissimilar letters differ significantly as per DMRT. $T_{1}=N_{0}\left(\right.$ Control); $T_{2}=N_{65} ; T_{3}=N_{50 \%}+U S(15 \%) ; T_{4}=N_{50 \%}+U S(20 \%) ; T_{5}=N_{60}+$ US (15\%); $\mathrm{T}_{6}=\mathrm{N}_{100 \%}$ (Traditional method).

Table 3. Interaction effect of variety and foliar application of urea on the yield and yield contributing characters of BRRI dhan56 and Haridhan.

\begin{tabular}{llll}
\hline Interaction of variety and foliar application of urea & Plant height & Total tiller & Panicle length \\
\hline$V_{1} T_{1}$ & $104.13 \mathrm{e}$ & $11.47 \mathrm{c}$ & 24.23 \\
$\mathrm{~V}_{1} \mathrm{~T}_{2}$ & $111.73 \mathrm{~cd}$ & $12.40 \mathrm{c}$ & 24.67 \\
$\mathrm{~V}_{1} \mathrm{~T}_{3}$ & $114.73 \mathrm{bc}$ & $11.93 \mathrm{c}$ & 26.35 \\
$\mathrm{~V}_{1} \mathrm{~T}_{4}$ & $111.40 \mathrm{~cd}$ & $12.33 \mathrm{c}$ & 24.69 \\
$\mathrm{~V}_{1} \mathrm{~T}_{5}$ & $111.50 \mathrm{~cd}$ & $12.00 \mathrm{c}$ & 24.68 \\
$\mathrm{~V}_{1} \mathrm{~T}_{6}$ & $109.33 \mathrm{~d}$ & $11.40 \mathrm{c}$ & 24.72 \\
$\mathrm{~V}_{2} \mathrm{~T}_{1}$ & $120.20 \mathrm{a}$ & $14.67 \mathrm{~b}$ & 26.34 \\
$\mathrm{~V}_{2} \mathrm{~T}_{2}$ & $123.00 \mathrm{a}$ & $15.53 \mathrm{~b}$ & 26.43 \\
$\mathrm{~V}_{2} \mathrm{~T}_{3}$ & $122.27 \mathrm{a}$ & $15.20 \mathrm{~b}$ & 25.73 \\
$\mathrm{~V}_{2} \mathrm{~T}_{4}$ & $118.73 \mathrm{ab}$ & $17.73 \mathrm{a}$ & 27.72 \\
$\mathrm{~V}_{2} \mathrm{~T}_{5}$ & $122.80 \mathrm{a}$ & $14.80 \mathrm{~b}$ & 26.71 \\
$\mathrm{~V}_{2} \mathrm{~T}_{6}$ & $123.13 \mathrm{a}$ & $15.53 \mathrm{~b}$ & 26.31 \\
$\mathrm{CV}$ (\%) & 3.25 & 5.01 & 5.62 \\
Level of sig. & $*$ & $*$ & $\mathrm{NS}$ \\
\hline
\end{tabular}

${ }^{*}=$ Significant at $5 \% \quad{ }^{* *}=$ Significant at $1 \% \quad$ NS=Non-significant; In a column, figures with same letter or without letter do not differ significantly whereas figures with dissimilar letters differ significantly as per DMRT. $T_{1}=N_{0}\left(\right.$ Control); $T_{2}=N_{65 \%} ; T_{3}=50 \%+U S(15 \%) ; T_{4}=N_{50 \%}+U S(20 \%) ; T_{5}=$ $\mathrm{N}_{60 \%}+$ US (15\%); $\mathrm{T}_{6}=\mathrm{N}_{100 \%}$ (Traditional method); $\mathrm{V}_{1}=\mathrm{BRRI}$ dhan56; $\mathrm{V}_{2}=$ Haridhan. 
Table 4. Effect of variety on yield and yield contributing characters of BRRI dhan 56 and Haridhan.

\begin{tabular}{lccccccc}
\hline Variety & $\begin{array}{c}\text { Effective } \\
\text { tiller hill }\end{array}$ & $\begin{array}{c}\text { Grain } \\
\text { panicle }^{-1}\end{array}$ & $\begin{array}{c}\text { Weight of } \\
\text { 1000 seeds (g) }\end{array}$ & $\begin{array}{c}\text { Grain yield } \\
\text { (t/ha) }\end{array}$ & $\begin{array}{c}\text { Straw yield } \\
\text { (t/ha) }\end{array}$ & $\begin{array}{c}\text { Biological } \\
\text { yield (t/ha) }\end{array}$ & $\begin{array}{c}\text { Harvest } \\
\text { index (\%) }\end{array}$ \\
\hline BRRI dhan56 & 10.53 & 126.82 & 25.19 & 5.51 & 6.21 & 11.72 & 47.01 \\
Haridhan & 11.19 & 166.55 & 25.94 & 6.08 & 6.45 & 12.53 \\
CV (\%) & 6.66 & 3.63 & 4.77 & 3.92 & 3.39 & 4.18 & 4.44 \\
Level of sig. & $* *$ & $* *$ & NS & $* *$ & $* *$ & $* *$ & $* *$ \\
\hline
\end{tabular}

${ }^{*}=$ Significant at $5 \%,{ }^{* *}=$ Significant at $1 \%$, NS $=$ Non significant.

Table 5. Effect of foliar spray of urea on the yield and yield contributing characters of BRRI dhan56 and Haridhan.

\begin{tabular}{lccccccc}
\hline Treatment & $\begin{array}{c}\text { Effective } \\
\text { tiller hill }\end{array}$ & $\begin{array}{c}\text { Grain } \\
\text { panicle }^{-1}\end{array}$ & $\begin{array}{c}\text { Weight of } \\
\text { 1000 seeds (g) }\end{array}$ & $\begin{array}{c}\text { Grain yield } \\
\text { (t/ha) }\end{array}$ & $\begin{array}{c}\text { Straw yield } \\
\text { (t/ha) }\end{array}$ & $\begin{array}{c}\text { Biological } \\
\text { yield (t/ha) }\end{array}$ & $\begin{array}{c}\text { Harvest } \\
\text { index (\%) }\end{array}$ \\
\hline $\mathrm{T}_{1}$ & $9.88 \mathrm{c}$ & $131.79 \mathrm{e}$ & 25.47 & $5.15 \mathrm{c}$ & $5.82 \mathrm{~b}$ & $10.97 \mathrm{c}$ & 46.90 \\
$\mathrm{~T}_{2}$ & $11.27 \mathrm{ab}$ & $152.68 \mathrm{~b}$ & 25.62 & $5.91 \mathrm{~b}$ & $6.43 \mathrm{a}$ & $12.34 \mathrm{ab}$ & 47.87 \\
$\mathrm{~T}_{3}$ & $10.80 \mathrm{bc}$ & $139.81 \mathrm{~d}$ & 25.42 & $5.82 \mathrm{~b}$ & $6.33 \mathrm{a}$ & $12.15 \mathrm{~b}$ & 47.88 \\
$\mathrm{~T}_{4}$ & $12.11 \mathrm{a}$ & $156.91 \mathrm{a}$ & 26.22 & $6.14 \mathrm{a}$ & $6.41 \mathrm{a}$ & $12.54 \mathrm{a}$ & 48.92 \\
$\mathrm{~T}_{5}$ & $10.60 \mathrm{bc}$ & $148.33 \mathrm{c}$ & 25.23 & $5.87 \mathrm{~b}$ & $6.53 \mathrm{a}$ & $12.41 \mathrm{ab}$ & 47.34 \\
$\mathrm{~T}_{6}$ & $10.51 \mathrm{bc}$ & $150.58 \mathrm{bc}$ & 25.43 & $5.89 \mathrm{~b}$ & $6.46 \mathrm{a}$ & $12.35 \mathrm{ab}$ & 47.63 \\
$\mathrm{CV}$ (\%) & 6.66 & 3.63 & 4.77 & 3.92 & 3.39 & 4.18 & 4.44 \\
Level of sig. & $* *$ & $* *$ & $\mathrm{NS}$ & $* *$ & $* *$ & $* *$ \\
\hline
\end{tabular}

*= Significant at $5 \% \quad{ }^{* *}=$ Significant at $1 \% \quad$ NS=Non significant; In a column, figures with same letter or without letter do not differ significantly whereas figures with dissimilar letters differ significantly as per DMRT. $T_{1}=N_{0}$ (Control); $T_{2}=N_{65 \%} ; T_{3}=N_{50 \%}+U S(15 \%) ; T_{4}=N_{50 \%}+U S(20 \%) ; T_{5}=$ $\mathrm{N}_{60 \%}+$ US (15\%); $\mathrm{T}_{6}=\mathrm{N}_{100 \%}$ (Traditional method).

Table 6. Interaction effect of variety and foliar application of urea on the yield and yield contributing characters of BRRI dhan56 and Haridhan.

\begin{tabular}{|c|c|c|c|c|c|c|c|}
\hline $\begin{array}{l}\text { Interaction of variety and foliar } \\
\text { application of urea }\end{array}$ & $\begin{array}{l}\text { Effective } \\
\text { tiller }\end{array}$ & $\begin{array}{l}\text { Grain / } \\
\text { panicle }\end{array}$ & $\begin{array}{c}\text { Weight } \\
\text { of } 1000 \\
\text { seeds }\end{array}$ & $\begin{array}{l}\text { Grain } \\
\text { yield } \\
\text { (t/ha) }\end{array}$ & $\begin{array}{l}\text { Straw } \\
\text { yield } \\
\text { (t/ha) }\end{array}$ & $\begin{array}{c}\text { Biological } \\
\text { yield } \\
\text { (t/ha) }\end{array}$ & $\begin{array}{l}\text { Harvest } \\
\text { index }\end{array}$ \\
\hline$V_{1} T_{1}$ & 9.47 & $116.20 \mathrm{i}$ & 25.40 & $4.68 f$ & 5.57 & $10.25 \mathrm{~g}$ & 45.64 \\
\hline$V_{1} T_{2}$ & 10.80 & 127.70g & 25.33 & $5.66 \mathrm{cde}$ & 6.37 & $12.03 \mathrm{def}$ & 47.04 \\
\hline$V_{1} T_{3}$ & 10.33 & $122.73 \mathrm{~h}$ & 24.80 & $5.70 \mathrm{cde}$ & 6.19 & 11.89ef & 47.92 \\
\hline$V_{1} T_{4}$ & 11.29 & $133.28 f$ & 26.20 & $5.84 \mathrm{bcd}$ & 6.18 & $12.02 \mathrm{def}$ & 48.62 \\
\hline$V_{1} T_{5}$ & 10.87 & $131.35 \mathrm{fg}$ & 24.53 & $5.76 \mathrm{cde}$ & 6.60 & $12.36 \mathrm{cde}$ & 46.61 \\
\hline$V_{1} T_{6}$ & 10.42 & $129.65 \mathrm{fg}$ & 24.87 & $5.45 \mathrm{e}$ & 6.34 & $11.78 f$ & 46.23 \\
\hline $\mathrm{V}_{2} \mathrm{~T}_{1}$ & 10.30 & 147.37e & 25.53 & 5.63de & 6.06 & $11.69 f$ & 48.16 \\
\hline$V_{2} T_{2}$ & 11.73 & $177.65 a$ & 25.90 & 6.16ab & 6.49 & $12.64 \mathrm{abc}$ & 48.69 \\
\hline$V_{2} T_{3}$ & 11.27 & $156.89 d$ & 26.03 & $5.93 \mathrm{bcd}$ & 6.47 & $12.41 \mathrm{~cd}$ & 47.84 \\
\hline $\mathrm{V}_{2} \mathrm{~T}_{4}$ & 12.93 & $180.53 a$ & 26.23 & 6.43a & 6.63 & 13.06a & 49.22 \\
\hline $\mathrm{V}_{2} \mathrm{~T}_{5}$ & 10.33 & $165.32 \mathrm{c}$ & 25.93 & $5.98 b c$ & 6.46 & $12.45 \mathrm{bcd}$ & 48.07 \\
\hline$V_{2} T_{6}$ & 10.60 & $171.52 b$ & 26.00 & 6.33a & 6.58 & 12.91ab & 49.03 \\
\hline CV (\%) & 6.66 & 3.63 & 4.77 & 3.92 & 3.39 & 4.18 & 4.44 \\
\hline Level of sig. & NS & $* *$ & NS & $* *$ & NS & $* *$ & NS \\
\hline
\end{tabular}

${ }^{*}=$ Significant at $5 \% \quad{ }^{* *}=$ Significant at $1 \% \quad$ NS=Non significant; In a column, figures with same letter or without letter do not differ significantly whereas figures with dissimilar letters differ significantly as per DMRT. $T_{1}=N_{0}$ (Control); $T_{2}=N_{65 \%} ; T_{3}=N_{50 \%}+$ US (15\%); $T_{4}=N_{50 \%}+$ US (20\%); $T_{5}=$ $\mathrm{N}_{60 \%}+$ US (15\%); $\mathrm{T}_{6}=\mathrm{N}_{100 \%}$ (Traditional method); $\mathrm{V}_{1}=$ BRRI dhan56; $\mathrm{V}_{2}=$ Haridhan.

Panicle length $(\mathrm{cm})$

BRRI dhan56 produced panicle length $24.89 \mathrm{~cm}$ whereas Haridhan produced panicle length $26.54 \mathrm{~cm}$ (Table 1). The difference between the varieties might be due to genetic variation. This result is in agreement with the findings of Ali et al. (2014); Hossain et al. (2014); Shiyam et al. (2014); Sarker et al. (2013); Baset Mia and Shamsuddin (2011); Jeng et al. (2009) and Bakul et al. (2009). They also found variation in panicle length due to the variation in genetic make-up of the varieties of rice. Highest panicle length $(26.21 \mathrm{~cm})$ was found from $\mathrm{T}_{4}$ treatment when $20 \%$ urea was used as foliar spray and lowest panicle length $(25.29 \mathrm{~cm})$ was found from $T_{1}$ treatment (control plot). Results showed that panicle length $(\mathrm{cm})$ was not significantly affected by the foliar application of urea. Panicle length $(24.72 \mathrm{~cm})$ was obtained from BRRI dhan 56 in $\mathrm{T}_{6}$ treatment and highest panicle length $\left(26.35 \mathrm{~cm}\right.$ ) obtained from $\mathrm{T}_{3}$ treatment (when 15\% urea used for spray). Highest panicle length $(27.72 \mathrm{~cm})$ was obtained from Haridhan in $\mathrm{T}_{4}$ treatment (when 20\% urea used for spray) and $\mathrm{T}_{3}$ treatment produced lowest panicle length $(25.73 \mathrm{~cm})$ when $15 \%$ urea used for spray. The result of the study is in agreement with that of the finding of (Jamal, 2006) who also observed insignificant influence of interaction of variety and foliar spray of urea on panicle length (Table 3). 
Yield and yield contributing characters and harvest index

Effective tillers hill ${ }^{-1}$

Higher number of effective tillers hill ${ }^{-1}$ (12.93) was found in Haridhan and BRRI dhan56 (11.29) (Table 4). The probable reasons of difference in producing the number of effective tillers hill $^{-1}$ was mainly genetic makeup of the variety. These findings corroborate with that of BINA (1998), Om et al. (1998), Bhowmick and Nayak (2000) who stated that number of effective tillers hill ${ }^{-1}$ varied with the varieties. Foliar spray of urea showed significant influence on the production of effective tillers hill ${ }^{-1}$ (Table 5). The highest number of effective tillers hill $^{-1}$ (12.11) was obtained from $\mathrm{T}_{4}$ treatment when $20 \%$ urea was applied as foliar spray which was higher than $\mathrm{T}_{2}$ and $\mathrm{T}_{6}$ treatment when $65 \%$ and $100 \%$ urea was used as traditional method. Interaction effect on variety from this study we found that foliar application has significant influence on effective tillers hill ${ }^{-1}$ (Table 6).

\section{Grains panicle ${ }^{-1}$}

The number of grains panicle ${ }^{-1}$ (126.82) in BRRI dhan 56 was statistically lower than Haridhan (166.55) (Table 4). The variation in filled grains production between varieties might be due to their genetic makeup. Uddin et al. (2011) reported the similar findings with the present study where they found that the significant differences were found in filled grains panicle ${ }^{-1}$ while BRRI dhan44 excelled significantly (97.67) and Lalchicon produced the lowest one (63.00). The highest grain panicle ${ }^{-1}$ (156.91) was obtained from $\mathrm{T}_{4}$ treatment when $20 \%$ urea was applied as foliar spray method which was higher than $\mathrm{T}_{2}$ and $\mathrm{T}_{6}$ treatment when $65 \%$ and $100 \%$ urea was applied as traditional method). So significant variation in grain yield was observed in BRRI dhan56 and Haridhan due to the foliar application of urea (Table 5). The highest grain panicle ${ }^{-1}$ (133.28) and (180.53) was obtained from BRRI dhan 56 and Haridhan in $T_{4}$ treatment which is higher than $T_{2}$ and $\mathrm{T}_{6}$ treatment. So interaction effect of variety and foliar application of urea was significant effect on grains panicle ${ }^{-1}$ (Table 6).

\section{Thousand grain weight}

Thousand grains weight did not significantly vary due to varieties (Table 4). BRRI dhan56 showed 1000 -grain weight $25.19 \mathrm{~g}$ and Haridhan showed1000-grain weight $25.94 \mathrm{~g}$. Urea spray on foliage did not show significant influence on thousand grain weight in BRRI dhan56 and Haridhan (Table 5). Numerically the highest 1000-grains weight (26.20g) was found in BRRI dhan56 in $\mathrm{T}_{4}$ treatment (when $20 \%$ urea was applied as foliar spray) and lowest 1000-grains weight (25.40) was found from $T_{1}$ treatment (control plot). So there is no significant difference between them (Table 6).

\section{Grain yield}

BRRI dhan56 produced 5.51 tha $^{-1}$ and Haridhan produced grain yield 6.08tha ${ }^{-1}$. The highest yield in Haridhan might be attributed to the production of maximum effective tillers $\mathrm{m}^{-2}$ and filled grains panicle ${ }^{-1}$. Ali et al. (2014); Shiyam et al. (2014); Uddin et al. (2011) and Ashrafuzzaman et al. (2009) reported that the variety which produced higher number of effective tillers hill ${ }^{-1}$ and higher number of grains panicle ${ }^{-1}$ showed higher grain yield ha- ${ }^{-1}$. The highest grain yield $\left(6.14 \mathrm{t} \mathrm{ha}^{-1}\right)$ was obtained from $\mathrm{T}_{4}$ treatment when $20 \%$ urea was applied as foliar spray which was higher than $\mathrm{T}_{2}$ and $\mathrm{T}_{6}$ treatment when $65 \%$ and $100 \%$ urea was applied as traditional method. Foliar application of urea might be the contribution of more number of effective tiller hill $^{-1}$, grains panicle ${ }^{-1}$ and lowest number of sterile spikelets panicle ${ }^{-1}$. The highest grain yield $\left(5.84\right.$ tha $\left.^{-1}\right)$ was obtained from BRRI dhan56 in $\mathrm{T}_{4}$ treatment (when $20 \%$ urea was applied as foliar spray) and lowest grain yield $\left(5.45\right.$ tha $\left.^{-1}\right)$ was recorded from $\mathrm{T}_{6}$ treatment when $100 \%$ urea was applied as traditional method. Highest grain yield $\left(6.43\right.$ tha $^{-1}$ ) was obtained from Haridhan in $\mathrm{T}_{4}$ treatment (when $20 \%$ urea was applied as foliar spray) which was higher than $\mathrm{T}_{6}$ treatment when $100 \%$ urea was applied as traditional method. Interaction effect of variety and foliar application of urea has significant effect on grain yield (Table 6).

Table7. Effect of variety on yield and yield contributing characters of BRRI dhan56 and Haridhan.

\begin{tabular}{lll}
\hline Variety & Non effective tiller hill ${ }^{-1}$ & Sterile spikelets Panicle $^{-1}$ \\
\hline BRRI dhan56 & 1.39 & 25.09 \\
Haridhan & 4.38 & 39.66 \\
CV (\%) & 12.59 & 7.34 \\
Level of sig. & $* *$ & $* *$ \\
\hline
\end{tabular}

${ }^{*}=$ Significant at $5 \%,{ }^{* *}=$ Significant at $1 \%$, NS=Non-significant.

Table 8. Effect of foliar spray of urea on the yield and yield contributing characters of BRRI dhan56 and Haridhan.

\begin{tabular}{lll}
\hline Treatment & Non effective tiller hill $^{-1}$ & Sterile spikelets panicle $^{-1}$ \\
\hline $\mathrm{T}_{1}$ & 3.18 & $40.65 \mathrm{a}$ \\
$\mathrm{T}_{2}$ & 2.70 & $33.40 \mathrm{~b}$ \\
$\mathrm{~T}_{3}$ & 2.77 & $31.16 \mathrm{~b}$ \\
$\mathrm{~T}_{4}$ & 2.92 & $32.40 \mathrm{~b}$ \\
$\mathrm{~T}_{5}$ & 2.80 & $25.29 \mathrm{c}$ \\
$\mathrm{T}_{6}$ & 2.96 & $31.33 \mathrm{~b}$ \\
$\mathrm{CV}(\%)$ & 12.59 & 7.34 \\
Level of sig. & $\mathrm{NS}$ & $* *$ \\
\hline
\end{tabular}

${ }^{*}=$ Significant at $5 \%,{ }^{* *}=$ Significant at $1 \%, \mathrm{NS}=$ Non-significant. In a column, figures with same letter or without letter do not differ significantly whereas figures with dissimilar letters differ significantly as per DMRT. $T_{1}=N_{0}$ (Control); $T_{2}=N_{65} ; T_{3}=N_{50 \%}+U S(15 \%) ; T_{4}=N_{50 \%}+U S(20 \%) ; T_{5}=N_{60}+$ US (15\%); $T_{6}=N_{100 \%}$ (Traditional method). 
Table 9. Interaction effect of variety and foliar application of urea on the yield and yield contributing characters of BRRI dhan56 and Haridhan.

\begin{tabular}{lll}
\hline $\begin{array}{lll}\text { Interaction of variety and foliar } \\
\text { application of urea }\end{array}$ & Non effective tiller hill ${ }^{-1}$ & Sterile spikelets Panicle $^{-1}$ \\
\hline$V_{1} T_{1}$ & 2.00 & $35.86 \mathrm{~cd}$ \\
$\mathrm{~V}_{1} \mathrm{~T}_{2}$ & 1.60 & $24.64 \mathrm{ef}$ \\
$\mathrm{V}_{1} \mathrm{~T}_{3}$ & 1.60 & $24.45 \mathrm{ef}$ \\
$\mathrm{V}_{1} \mathrm{~T}_{4}$ & 1.04 & $26.33 \mathrm{e}$ \\
$\mathrm{V}_{1} \mathrm{~T}_{5}$ & 1.13 & $18.03 \mathrm{~g}$ \\
$\mathrm{~V}_{1} \mathrm{~T}_{6}$ & 0.98 & $21.21 \mathrm{fg}$ \\
$\mathrm{V}_{2} \mathrm{~T}_{1}$ & 4.37 & $45.43 \mathrm{a}$ \\
$\mathrm{V}_{2} \mathrm{~T}_{2}$ & 3.80 & $42.17 \mathrm{ab}$ \\
$\mathrm{V}_{2} \mathrm{~T}_{3}$ & 3.93 & $37.86 \mathrm{bc}$ \\
$\mathrm{V}_{2} \mathrm{~T}_{4}$ & 4.80 & $38.47 \mathrm{bc}$ \\
$\mathrm{V}_{2} \mathrm{~T}_{5}$ & 4.47 & $32.55 \mathrm{~d}$ \\
$\mathrm{~V}_{2} \mathrm{~T}_{6}$ & 4.93 & $41.45 \mathrm{ab}$ \\
$\mathrm{CV}(\%)$ & 12.59 & 7.34 \\
Level of sig. & $\mathrm{NS}$ & $* *$ \\
\hline
\end{tabular}

${ }^{*}=$ Significant at $5 \% \quad{ }^{* *}=$ Significant at $1 \% \quad$ NS=Non significant; In a column, figures with same letter or without letter do not differ significantly whereas figures with dissimilar letters differ significantly as per DMRT; $T_{1}=N_{0}$ (Control); $T_{2}=N_{65 \%} ; T_{3}=N_{50 \%}+U S(15 \%) ; T_{4}=N_{50 \%}+U S(20 \%) ; T_{5}=$ $\mathrm{N}_{60 \%}+$ US (15\%); $\mathrm{T}_{6}=\mathrm{N}_{100 \%}$ (Traditional method); $\mathrm{V}_{1}=$ BRRI dhan56; $\mathrm{V}_{2}=$ Haridhan.

\section{Straw yield}

Variety was significantly influenced on straw yield (Table 4). The variety BRRI dhan56 produced straw yield (6.21 tha $\left.{ }^{-1}\right)$ and Haridhan produced straw yield $\left(6.45\right.$ tha $\left.^{-1}\right)$. In straw yield significant variation was observed in BRRI dhan 56 and Haridhan due to the foliar application of urea (Table 5).The highest straw yield $\left(6.53\right.$ tha $^{-1}$ ) was obtained from $\mathrm{T}_{5}$ treatment when $15 \%$ urea was applied as foliar spray which was significantly superior to that of traditional method of urea application. The lowest straw yield (5.82 tha $^{-1}$ ) was obtained from $\mathrm{T}_{1}$ treatment (control plot). In straw yield significant variation was not observed in BRRI dhan56 and Haridhan due to interaction of variety and foliar application of urea (Table 6).

\section{Biological yield}

Variation of biological yield among the varieties might be due to the genetic makeup of the studied varieties. Similar results were found supported by Uddin et al. (2011) who reported that the BRRI dhan44 produced higher biological yield than Lalchicon. The highest biological yield (12.54tha ${ }^{-1}$ ) was obtained from $\mathrm{T}_{4}$ treatment when $20 \%$ urea was applied as foliar spray which was significantly superior to that of $\mathrm{T}_{2}$ and $\mathrm{T}_{6}$ treatment. Biological yield was significantly influenced by interaction of variety and foliar application of urea (Table 6). The highest biological yield in BRRI dhan56 (12.36 tha ${ }^{-1}$ ) and Haridhan (13.06tha ${ }^{-1}$ ) was obtained from $T_{5}$ and $T_{4}$ treatment which was higher than $T_{6}$ treatment when $100 \%$ urea was applied as traditional method.

\section{Harvest index (\%)}

Variety showed significant influence on harvest index (Table 4). However, statistically BRRI dhan56 gave lower harvest index (47.01\%) than Haridhan gave higher harvest index (48.50\%). Foliar spray of urea did not show any significant influence on harvest index (Table 5). Interaction effect of variety and foliar application of urea did not show any significant influence on harvest index (Table 6).

\section{Yield retarding characters}

Non-effective tillers hill ${ }^{-1}$

Statistically the higher number of non-effective tillers hill $^{-1}$ (1.39) was found in BRRI dhan56 and Haridhan produced higher number of non-effective tillers hill $^{-1}$ (4.38). The result shows that variety had significant effect on non-effective tillers hill $^{-1}$. Foliage and traditional application of urea did not show significant influence in producing number of non-effective tillers hill ${ }^{-1}$ in BRRI dhan56 and Haridhan (Table 8).The lowest number of non-effective tillers hill $^{-1}(2.70)$ was found from $\mathrm{T}_{2}$ treatment when $65 \%$ urea was applied as traditional method which was lower than $\mathrm{T}_{3}, \mathrm{~T}_{4}$ and $\mathrm{T}_{5}$ treatment when $15 \%$ and $20 \%$ urea was applied as foliar spray. Interaction of variety and foliar application of urea did not show significant influence in producing number of non-effective tillers hill $^{-1}$ in BRRI dhan56 and Haridhan (Table 9).

Sterile spikelet panicle ${ }^{-1}$

The highest number of sterile spikelets panicle ${ }^{-1}$ (25.09) was obtained from BRRI dhan56 and (26.54) was obtained from Haridhan . So varietal effect present. The lowest number of sterile spikelets panicle ${ }^{-1}$ (25.29) was obtained from $T_{5}$ treatment. The highest number of sterile spikelets panicle ${ }^{-1}(40.65)$ was produced from $T_{1}$ treatment (control plot). Lowest number of sterile spikelets panicle ${ }^{-1}$ (35.86) was obtained with the interaction of variety BRRI dhan56 and treatment $T_{5}$. Lowest number of sterile spikelets panicle ${ }^{-1}$ (32.55) was obtained from interaction of Haridhan and $\mathrm{T}_{5}$ treatment which was lower than $\mathrm{V}_{2} \mathrm{~T}_{2}$ treatment when $65 \%$ urea applied as traditional method. 


\section{Conclusion}

Foliar application of urea solution at different concentrations had significant effect on yield and yield components BRRI dhan56 and Haridhan except number of non-effective tiller, panicle length, weight of 1000 seeds and harvest index. The result revealed that highest grain yield $\left(6.14\right.$ tha $\left.^{-1}\right)$ was obtained from foliar application of urea i.e. when $50 \%$ of recommended dose of urea was applied as soil application and $20 \%$ was applied as foliar. The lowest grain yield was obtained from the treatment with no urea application $\left(\mathrm{N}_{0}\right)$. From the experiment it can be concluded that the yield and yield contributing characters greatly influenced by urea foliar application method in rice crop. This will help rice cultivating farmers to save at least an amount of $20 \%$ recommended dose of urea fertilizer and can contribute to national economy of Bangladesh.

\section{ACKNOWLEDGEMENT}

The authors greatly acknowledge the Ministry of Science and Technology (MoST-39.009.002.01.00.053.2014-2015/Bs-36) Peoples Republic of Bangladesh for providing financial support to conduct the research work.

\section{Conflict of interests}

The authors declare that there is no conflict of interests regarding the publication of this paper.

Open Access: This is an open access article distributed under the terms of the Creative Commons Attribution 4.0 License, which permits unrestricted use, distribution, and reproduction in any medium, provided the original author(s) if the sources are credited.

\section{REFERENCES}

AIS (Agricultural Information Service). (2008). Krishi Dairy. Agril. Inform. Ser. Khamarbari, Farmgate, Dhaka. Bangladesh. pp. 23.

Akter, R. (2017). Performance of boro rice (BRRI dhan29) as affected by deep placement and foliar application of urea fertilizer. Research on Agriculture livestock and Fisheries, 5(2): 157-164.

Ali, M.H. Rahman, M.A. and Ullah, M.J. (1990). Effect of plant population and nitrogen on yield and yield content of rapeseed (Brassica campestris). Indian Journal of Agricultural Science, 60(9): 627-630.

Ashrafuzzaman, M., Islam, M.R., Shahidullah, S.M. and Hanafi, M.M. (2009). Evaluation of six aromatic rice varieties for yield and yield contributing Characters. International Journal of Agriculture and Biology, 11: 616-620.

Bakul, M.R.A., Akter, M.S., Islam, M.N., Chowdhury, M.M.A.A. and Amin, M.H.A (2009). Water stress effect on morphological characters and yield attributes in some mutants T aman rice lines. Bangladesh Research Publication Journal, 3 (2): 934-944.

Baset Mia, M.A. and Shamsuddin, Z.H. (2011). Physio-morphological appraisal of aromatic fine rice (Oryza sativa L.) in relation to yield potential. International Journal of Botany, 7(3): 223-229.

BBS (Bangladesh Bureau of Statistics). (2011). The Yearbook of Agricultural Statistics of Bangladesh. Statistics Div., Minis. Plan. Govt. peoples Repub., Bangladesh, Dhaka.p.54.

BBS (Bangladesh Bureau of Statistics). (2017). Statistical pocket book of Bangladesh. Bureau of Statistics, Statistics Division, Ministry of planning,
Government of the People's Republic of Bangladesh, pp. 34, 39

Bhowmick, N. and Nayak, R.L. (2000). Response of hybrid rice (Oryza sativa) varieties to nitrogen, phosphorus and potassium fertilizers during dry (boro) season in west Bengal. Indian Journal of Agronomy, 45(2): 323-326.

BINA (Bangladesh Institute of Nuclear Agriculture). (1998). Technical Report on Hybrid Rice Alok 6201. Div. Agron., Bangladesh Inst. Nuc. Agric., Mymensingh. pp. 1-3.

FAO and UNDP (Food and Agricultural Organization and United Nations Development Program), (1988). Land Resources Appraisal of Bangladesh for Agricultural Development. Report 2. Agro-ecological Regions of Bangladesh FAO, UNDP, Rome. pp. 116.

Hossain, M.S., Sobahan, M.A., Alam, M.A., Ali, M.S. and Bhuiyan, M.S.H. (2007). Effect of organic manures and nitrogen levels on plant height and number of tillers hill ${ }^{-1}$ of transplant Aman rice. Journal of Subtropical Agriculture Research and Development, 5(3): 291-296

Hossain, M.M., Sultana, F. and Asadur Rahman, A.H.M. (2014). A comparative screening of hybrid, modern varieties and local rice cultivar for brown leaf spot disease susceptibility and yield performance. Archives of Phytopathology and Plant Protection, 47(7): 795-802.

Islam, M.S., Sarkar, M.A.R., Uddin, S. and Parvin, S. (2012). Yield of fine rice varieties as influenced by integrated management of poultry manure urea super granules and prilled urea. Journal of Environmental Science and Natural Resources, 5(1): 129-132.

Jaiswal, V.P. and Singh, G.R. (2001). Performance of Urea Super Granules and Prilled Urea under different planting methods in irrigated rice (Oryza sativa). Indian Journal of Agricultural Science, 71(3): 187-189.

Jamal, Z., Hamyadan, M., Ahmed, N. and Fayaz, M. (2006). Effect of soil and foliar application of different concentration of NPK and foliar application of $\mathrm{NH}_{4}$ on different parameters in wheat. Journal of Agronomy, 5(2): 25 1-256.

Jeng, C.Z. and Xu, Y. (1989). Effect of sulphur deficient rice planting areas of Yunnam, China. Sulphur Agric. 13: 19-21.

Kabir, M.E., Kabir, M.R., Jahan, M.S. and Das, G.G. (2004). Yield performance of three aromatic fine rice in a coastal medium high land. Asian Journal of Plant Science, 3 (5): 561-563

Moeini, M., Baghestani, M.A. and Mashadi, H.R. (2006). Possibility of foliar application of urea and selective herbicides in wheat (Triticum aestivum L.). Applied Entomology, 74(1): $49-52$.

Nuruzzaman, M., Yamamoto, Y., Nitta, Y., Yoshida, T. and Miyazaki, A. (2000). Varietal Differences in Tillering Ability of Fourteen Japonica and Indica Rice Varieties. Soil Science and Plant Nutrition, 46(2): 381-391.

Om, H., Dhiman, S.D., Nandal, D.P. and Verma, S.L. (1998). Effect of method of nursery raising and nitrogen on growth and yield of hybrid rice (Oryza sativa). Indian Journal of Agronomy, 43(1), 68-70.

Sabnam, F. (2013). Effect of prilled urea, urea super granule and NPK briquettes under continuous flooded condition on N use efficiency and yield of BR22 rice. MS Thesis. Department of soil science, Faculty of Agriculture, Bangladesh Agricultural University, Mymensingh.

Sarker, A.K. (2012). Effect of Variety and Nitrogen Level on Yield and Yield Performance of transplanted Aman Rice. M.S Thesis in Agronomy, Bangladesh Agricultural University, Mymensingh. pp25.

Shiyam, J.O., Binang, W.B. and Ittah, M.A. (2014). Evaluation of growth and yield attributes of some lowland Chinese hybrid rice (Oryza sativa L.) varieties in the Coastal Humid Forest Zone of Nigeria. IOSR Journal of Agriculture and Veterinary Science, 7(2): 70-73.

Singh, R.V. and Chauhan, S.P.S. (2001). Response of mustard to the levels and sources of nitrogen with and without zinc in relation to yield and water use under dry land conditions. Bharatiya Krishi Anusandhan Patrika. 6:1

Statistica, (2018). The statistical portal. Download from http://www.statistica.com/statistics/255977/total-global-rice-consumption.

Tayeb, A., Paul, S. K. and Samad, M. A. (2013). Performance of variety and spacing on the yield and yield contributing characters of transplanted aman rice. Journal of Agroforestry and Environment, 40 (4): 595-597.

Uddin, M.J., Ahmed, S., Rashid, H.M., Hasan, M.A. and Asaduzzaman, M. (2011). Effect of spacing on the yield and yield attributes of transplanted aman rice varieties in medium lowland ecosystem of Bangladesh. Journal of Agriculture and Research, 49(4): 465-476.

Zhu, Z.L., Wan, Q.X. and Fernery, J.R. (1997). Nitrogen in Soils of China. Kluwer Academic Publishers, Dordrecht. 